\title{
Towards Understanding Some Selected Puns from Shakespeare's Dramas
}

\author{
Dr. Elrayah Eltahir Adam Khatir \\ Assistant Professor of English language, Faculty of Education, University of Bakht-er- Ruda, Sudan- Gassim University KSA
}

\begin{abstract}
This study presents an introductory account about Shakespeare and his style. It discusses briefly Shakespeare's language. It addresses Shakespeare's punning in particular, and definitions of pun as suggested by some scholars and linguists, how to recognize the existence of pun, its meanings and origins. The present study could be significant and original since it deals with the phenomenon of recognizing pun's in Shakespeare's drama, which is still a virgin ground, to a large extent. This study looks into the problems of rendering some Shakespeare's puns into focus of understanding. To understand puns one must understand people, their cultures, habits and beliefs. Despite the success of this indispensable tool of communication, it still wavers when being applied to drama which is the branch of literature that has been described as being the most challenging among all types of literature. To understand puns one also must understand the choice of words which are always the barrier that blocks the researchers efforts to bridge the gaps of understanding among nations and eventually among cultures. Explaining pun in Shakespeare's drama is the main concern of this study. The researcher will study in depth some examples of puns in Shakespeare's plays and subject them into focus of understanding.
\end{abstract}

Keywords: Understanding Shakespeare's Puns

\section{Statement of the problem}

Before directly addressing the problem, there seems to be a need to introduce the data to be analyzed and discussed. Pun is typically considered a distinct feature of the language it presents. Puns "are facts of language insofar as they depend on the structured characteristics of language as an abstract system" (Delabastita, 1996: 129). So, if a certain pun sees light only within the borders of the language, it is a part of it. How, then, is it going to be possible for a reader to understand language pun? Furthermore, how can the evidence of successful reader of certain types of Shakespeare's puns be justified?

This study is primarily intended to examine a certain problematic area in understanding shakespeare's pun. This problem is basically restricted to the understanding of puns in Shakespeare's plays where different strategies have been employed to accomplish the best understanding. Readers may face puns that are difficult to be understood. This research is based on the assumption that not only is pun a distinct feature of the language it presents, but it is also subject to the user of it. It is the punster who chooses the pun, chooses its context, and chooses its role, effect and function in the text in which it is employed. In this study, the researcher investigates the setting of puns with the emphasis being on the imprint of the punster on it.

\section{Significance of the Study}

To the best of the researcher's knowledge, most of what has been written on puns, involved two languages with the same root or a similar history. Few were those discussing the concept between two languages of different origins. Therefore, this study might occupy a promising role in filling a gap in the literature related to the understanding of pun, and in dragging the attention of other researchers to expand what this research has just started with. The significance of the present study stems from the fact that only few studies have touched upon it. Therefore, the current study deals with a phenomenon which is still, to a large extent, a virgin ground in the field of literature. The present study is an attempt to make a step further in the field of puns in general and in understanding of Shakespeare style of writing drama in particular. It differs from many other related studies in the fact that it is intended to address the issue of punning understanding. Hopefully, the results, recommendations and suggestions drawn from this particular study will sharpen the awareness ofunderstanding puns in Shakespeare's drama. It is also hoped to shed light on some of the problems pertaining to the readers of English puns in Shakespeare's dramas. It is also hoped that this study will provide some insights into the understanding of English utterancesincluding puns. Furthermore, the study is meant to shed more light on how readers should deal with puns where a term or an expression could have two or, even, three meanings, intentionally intended by the author.

\section{Purpose of the Study}

This study aims at investigating the understanding of some Shakespearian pun.It also investigate the main obstacles that might appear while rendering Shakespeare's puns into their understanding, with which it shares nothing but being two means of communication. Moreover its goal is to highlight the role the user of pun plays in both coining it, then interfering with its understanding. The researcher finds that this difference results from the readers' background and diction which sometimes prevents him from being able to decipher the message encapsulated in the original text. However, this choice of diction is not the only reason behind (for) such misunderstanding of Shakespeare's pun.

\section{Research Questions}

What are the main differences that the researcher has encountered in the various readers of Shakespeare's puns?

What are the strategies used by the readers to overcome the problems of misunderstanding? 


\section{International Journal of Science and Research (IJSR) \\ ISSN (Online): 2319-7064}

Index Copernicus Value (2013): 6.14 | Impact Factor (2014): 5.611

To what extent is the researcher governed by the imprint of the punster?

To what extent is the researcher successful in rendering the original puns?

\section{Methodology}

The method used in this study is to highlight problems in understanding puns through picking up examples of pun from Shakespeare's plays and their renditions into their understanding. The researcher will also collect and analyze some puns mentioned in Shakespeare's dramas. The success or failure of understanding will be judged on the extent to which the message conveyed appropriately into the context. The researcher comes up with different types of puns in Shakespeare's drama, namely common, Elizabethan, obvious, bawdy, grammatical, triple, homophonic and indecent one. Then examine to which extent this text is successful to the original from the researcher's viewpoint.

\section{Design of study}

The method used in this study is to highlight problems in translating puns through singling out examples of pun from Shakespeare's plays and critically interpret their meaning. In addition to collecting the puns, the researcher will sort out the puns in Shakespeare's drama into common, Elizabethan, obvious, bawdy, grammatical, triple, homophonic and indecent.

1. Explaining the two meanings of a pun using a nonpunning phrase.

2. Different rhetorical devices might be used in an attempt to re-create the effect of the original pun.

3. Omitting the part of the text which has the pun.

\section{Data Collection}

Ten puns of Shakespeare's drama mentioned in the Riverside of Shakespeare will be under the focus of the study.

\section{Review of Related Literature}

\section{What is Pun?}

Pun is a play on words, sometimes on different senses of the same word and sometimes on the similar sense or sound of different words.

To come to grips with the very nature of pun is somewhat elusive. There is a lack of a sole and specific view concerning the origin, definition, and the classification of this term - issues to be detailed in the following subsequent subsections.

\section{Origin of pun}

To figure out the origin of pun, Culler (1988: 1) cites a long paragraph from Swift (1957) presenting the following suggested origins of pun, with the exception of the last Italian one for which Culler (1988) consults Oxford Dictionary of English Etymology (1962). Fundum (means Bottom), Maniebriumgladij (means the handle of a sword), ponticulus, pungo, punaise, and puntiglio. The first two are indicated by a Greek word from which pun is thought to be derived. It is fundum because pun is "thought to lye deeper than any other" type of wit, but Manibriumgladij is because of the brightness and sharpness one creates when punning. Moreover, the French origin punaise "signifies a little stinking insect that gets into the skin, to provoke continual itching and is of great difficulty removed. The researcher was tempted to find the match between this French origin and the nature of pun, and here is the result: "Pun is a little amazing Rhetorical Feature that gets into the Mind of the Receptor, provokes continual Admiration and is with great difficulty to be forgotten."

\section{Definition of Pun}

Engaging one in finding a clear and specific definition of pun is burdensome. On the one hand, many authors do not go beyond presenting the major types of pun. On the other hand, others like Delabastita $(1996,1997)$, a famous name in dealing with pun and its translation, use the words pun and wordplay interchangeably; therefore, they present a definition of wordplay instead. Wordplay is the general term under which come the "textual phenomena" (Delabastita, 1996: 129). Therefore, pun is one way of manifesting wordplay. But, the fact that the former is a rhetorical feature distinguishes it from other types of the latter.

\section{According to Cuddon, J. A. in his 'A Dictionary of Literary Terms'}

\section{Pun is:}

"A figure of speech which involves a play upon words. One of the earliest types of wordplay, the pun is widespread in many literatures and gives a rise to a fairly universal form of humor. Puns are very often intended humorously but not always."

Even if one consults two dictionaries, for the meaning of pun, s/he might find a kind of disagreement between the two on the nature of it. While Oxford Dictionary (1974) emphasizes the humorous use of it, Webster's Dictionary (1991) emphasizes the "usually humorous" one. Doing so leaves room for employing this feature in 'serious' ways and situations. Wikipedia, the free encyclopedia, still presents a definition of pun which seems to be reasonable and comprehensive. Pun is:

A figure of speech which consists of a deliberate confusion of similar words or phrases for rhetorical effect, whether humorous or serious. A pun can rely on the assumed equivalency of multiple similar words (homonymy), of different shades of meaning of one word (polysemy), or of a literal meaning with a metaphor.

According to Addison (1988: 120), pun is "a conceit arising from the use of two words that agree in the sound, but differ in the sense" (Addison 1982, cited in Delabastita, 1996: 127), as in idlelidol, counsel/council. This essence of pun is proved by Culler (1988: 3) who puts the emphasis on "speaker's intention" with responding to the phoneme.

In the later stages, the concept developed exceeding similarity in sound to embrace that of form, too. In addition to homophones (two words which sound the same but differ in meaning), homographs (two words similar in spelling but

\section{Volume 4 Issue 12, December 2015}




\section{International Journal of Science and Research (IJSR) \\ ISSN (Online): 2319-7064}

Index Copernicus Value (2013): 6.14 | Impact Factor (2014): 5.611

different in meaning) and polysemy (one word with different shades of meaning) are inseparable from any attempt to define pun.

The difficulty of stating a specific definition of pun might arise from the fact that it is a mental activity. Pun is "so intrinsically part of our speech and thinking" and with a "pervasive and ubiquitous nature" (Delabastita, 1997: 2). The ability to manipulate words and 'pour them in new moulds' is a task which requires creativity. That is probably why some attempts at punning do not arouse the mind and are doomed to failure. But still, creating a pun does not only need a quick-witted mind to find matches between words and use them as punning, but also requires a high level of awareness, appreciation and perception of the language and the way it functions, according to Beekman and Callow (1974: 32).

Within the framework of our current research, the problem lies in the difficulty to shakerpeare understand punning. Many readers can play on words, but not all of them can amaze the receptors with their clever employments of, for example, one word that bears two meanings. And it is the receptor's task to read between the lines to reach the intended meaning. The question to be raised here is how much of the meaning is lost when pun is not understood well?!

\section{Classification of Pun}

Within the framework of this research endeavor, we adopt the belief that pun, as a type of wordplay,resists all kinds of typology.Although Delabastita (1997) presents the different attempts of Wurth (1895), Heller (1974), Freidhof (1984), and even his own,to establish a specific classification of wordplay, no one single study has embraced all subtypes of punning yet. We firmly believe that what fits as a reason behind the difficulty of defining pun fits with the difficulty of classifying it.

Despite this very fact, pun is still said - by different authors among whom are Leech (1969: 209), Newmark (1988: 217), Delabastita (1997: 5)- to be achieved, basically, through the employment of deep interpretation.

\section{How Ambiguity differs from a pun}

Mercutio in the example above is playing with the meaning of the word "grave," and thus this speech is often given as an example of a pun. In the loose meaning of the word "pun" as a play on words, then this example will work. In the speech by Mercutio, he is using the same word, "grave," with two different meanings that both apply. This technique gives the dialogue a greater richness, with a combination of condensing the speech and expanding the meaning.

Puns can be classified in various ways:

The homophonic pun, a common type, uses word pairs which sound alike (homophones) but are not synonymous. Walter Redfern exemplified this type with his statement "To pun is to treat homonyms as synonyms".For example, in George Carlin's phrase "Atheism is a non-prophet institution", the word "prophet" is put in place of its homophone "profit", altering the common phrase "non-profit institution". Often, puns are not strictly homophonic, but play on words of similar, not identical, sound as in the example from the "Pinky and the Brain" cartoon film series: "I think so, Brain, but if we give peas a chance, won't the lima beans feel left out?" which plays with the similar - but not identical - sound of "piece" and "peace". Rhymes are often used, such as in the example cited below of a wine shop called "Planet of the Grapes." This plays on the rhyme between "grapes" and "apes".

A homographic pun exploits words which are spelled the same (homographs) but possess different meanings and sounds. Because of their nature, they rely on sight more than hearing, contrary to homophonic puns. They are also known as heteronymic puns. Examples in which the punned words typically exist in two different parts of speech often rely on unusual sentence construction, as in the anecdote: "When asked to explain his large number of children, the pig answered simply: 'The wild oats of my sow gave us many piglets'. An example which combines homophonic and homographic punning is Douglas Adam's line "You can tune a guitar, but you can't tuna fish. Unless of course, you play bass." The phrase uses the homophonic qualities of "tune a" and "tuna", as well as the homographic pun on "bass", in which ambiguity is reached through the identical spellings of /'beis/ (a string instrument), and/'bæs/ (a kind of fish).

Homonymic puns, another common type, arise from the exploitation of words which are both homographs and homophones. The statement "Being in politics is just like playing golf: you are trapped in one bad lie after another" puns on the two meanings of the word lie as "a deliberate untruth" and as "the position in which something rests". An adaptation of a joke repeated by Isaac Asimov gives us "Did you hear about the little moron who strained himself while running into the screen door?" playing on 'strained' as "to give much effort" and "to filter". A homonymic pun may also be polysemic, in which the words must be homonymic and also possess related meanings, a condition which is often subjective.

A compound pun is a statement that contains two or more puns. For example, a complex statement by Richard Whately includes four puns: "Why can a man never starve in the Great Desert? Because he can eat the sand which is there. But what brought the sandwiches there? Why, Noah sent Ham, and his descendants mustered and bred." This pun uses "sand which is there/sandwiches there, "Ham /ham", "mustered/mustard", and "bred/bread". Compound puns may also combine two phrases that share a word.

A recursive pun is one in which the second aspect of a pun relies on the understanding of an element in the first. For example the statement "Infinity is not in finity," which means infinity is not in finite range.

\section{Hamlet (Act I scene II)}

Claudius: "...But now, my cousin Hamlet, and my son..."

Hamlet: [aside] "A little more than kin, and less than kind."

\section{Volume 4 Issue 12, December 2015}




\section{International Journal of Science and Research (IJSR) \\ ISSN (Online): 2319-7064}

Index Copernicus Value (2013): 6.14 | Impact Factor (2014): 5.611

Context: Hamlet is upset that his uncle Claudius has married his mother. Hint: Think of "kind" as also short for "kindred."

Below are some lines from some of William Shakespeare's plays and sonnets. You will find a pun in each set of lines in bold print. On the lines below each quote, briefly explain the pun as you think Shakespeare might have intended for his audience. Remember, a pun can be a humorous play on words that look or sound alike, but have different meanings. 2. I'll make a ghost of him that lets me!" Hamlet (Act i, S.4) Hint: In Shakespeare's day, "let" meant "hinder," and today means the opposite, "allow."

3. "If reasons were as plentiful as blackberries, I would give no man a reason upon compulsion, I." Henry IV, Part On (Act ii, S.4) Hint: "Reason" was pronounced "raisin" in Shakespeare's day.

\section{Shakespeare's Language}

It is understandable why people sometimes get a little overwhelmed when reading Shakespeare. You have got to contend with versification, poetic license, archaisms, words that we do not even use any more, and grammar and spelling that were in a state of flux when the works were written. The most striking feature of Shakespeare is his command of language.

For many people today, reading Shakespeare's language can be a problem - but it is a problem that can be solved. Modern readers may need to develop the skills of untangling unusual sentence structures and of recognizing and understanding poetic compressions, omissions, and wordplay. And even those skilled in reading unusual sentence structures may have occasional trouble with Shakespeare's words. Four hundred years of "static" caused by changes in language and life - intervene between his speaking and our hearing. Most of his immense vocabulary is still in use, but a few of his words are not, and, worse, some of his words now have meanings quite different from those they had in the sixteenth and seventeenth centuries.

Shakespeare has gained great life in Arabic. All of his works, the sonnets, narrative poems, and the plays have been transplanted in the fertile soil of Arabic. His plays have been worded by many translators of good circulation in Arab world such as: Anani, Mushati, Habib and Jebra.

In the theater, most of these difficulties are solved for us by actors who study the language and articulate it for us so that the essential meaning is heard- or, when combined with stage action, is at least felt. The language of Shakespeare's poems, like that of poetry in general, is both highly compressed and highly structured. While most often discussed in terms of its images and its metrical and other formal structures, the language of the poems, like that of Shakespeare's plays, also repays close attention to such basic linguistic elements as words, word order, and sentence structure.

One of the most difficult challenges of studying Shakespeare is breaking the language barrier. There are several factors that often confuse the reader about the language of Shakespeare, including, but not limited to, the use of obsolete words, the order of sentence wording, and puns that depended on the meaning, usage, and pronunciation of words. For the first time reader of Shakespeare, the text may seem confusing and hard to translate, but it is important to understand that Shakespeare did indeed write in English, just a slightly different version of what we consider to be modern English

Shakespeare's language is special. Stephen Booth points out that it is special in two ways, suggesting that:

Shakespeare's sentences do not always make sense and Shakespeare's language is exciting to the minds that hear it- exciting to minds because what is being said in a Shakespearian sentence often comes to us in a soup of possibilities, possibilities engendered by substantively negligible, substantively irrelevant relationships among elements in a syntax to which those relationships are filtered from consciousness. (2004: 21)

One may argue about the characteristic mentioned above wondering how we can understand sentences that do not make sense! But Booth goes on and explains what he means by this characteristic. He says that Shakespeare's words are understood through their connotative meaning rather than denotative one, and also the context of Shakespeare's words helps us to understand them.

\section{Denotative and connotative meanings}

Puns expressions are full of connotative meanings. In this section, the researcher discusses the differences between the denotative and connotative meanings particularly in the context of pun's expressions.

\section{Stylistics characteristics of Shakespeare}

Shakespeare refuses to lead the reader in the mazes of ambiguity. Instead, he presents his ideas and emotions on a 'plate of silver'. This is because he cares more, for delivering the message than for 'flexing his muscles' in his literary works.

The researcher here limits the discussion to those which are of benefit to the analysis and interpretation of puns in this study. The ones that mark the plays in which puns are employed are in which we are concerned.

\section{Functions of pun}

This part of the research will shed the light on some functions of pun. Now let us survey and analyze them along with their representative examples and how they are tackled into Arabic.

Avoiding getting trapped in a haphazard and confusing presentation and discussion of the selected some puns in the drama of Shakespeare, a specific classification is adopted; Shakespeare's puns are discussed according to their functions. The following issues can be discussed under the function: the role of the pun plays in the context, the place of its appearance in the play, the effect it introduces, and the context in which it is employed.

Delabastita (1996) presents the following functions of puns

\section{Volume 4 Issue 12, December 2015}




\section{International Journal of Science and Research (IJSR) \\ ISSN (Online): 2319-7064}

Index Copernicus Value (2013): 6.14 | Impact Factor (2014): 5.611

in texts: "possible functions include adding to the thematic coherence of the text, producing humor, forcing the reader/listener into greater attention, adding persuasive force to the statement, deceiving our socially conditioned reflex (taboos) against sexual and other taboo themes, and so forth." (Delabastita: 130)

Fearing of saying the truth and refusing to lie, some would pun on words. Moreover, they might do so to avoid possible undesirable "back clashes".

- Al-Safi (1996: 10) proposes a tri-criterion assessment. The first criterion is "accuracy". It refers to the preservation of meaning denotatively and connotatively between two different languages.

- It is taken for granted that the language of a literary work is carefully, artistically or aesthetically used. A literary author creates his work by employing "aesthetically pleasing diction, stylistic/rhetorical devices and wellmanipulated linguistic patterns". Any good reader has to make these characteristics into account in order to make his interpretative pun's meaning "as vivid and effective as the original". Otherwise, his meaning will be "tasteless, prosaic and lacking aesthetic pleasure".

- According to Al-Safi (1996: 16), two types of losses can be diagnosed in assessing literal work. Firstly, failing to transfer the "tone" of the original author as represented in his choice of words. The second type results from the absence of figures of speech that have played a vital role in beautifying the original writer's style and in making it creative.

\section{Shakespeare pun}

In 2005 and in a response to a question on the understandability of Shakespeare, Sir Peter Hall assumed that "Shakespeare is difficult to be understood." David Schalkwyk (2006: 37-48) argues that we can accept this answer for two reasons. The first is that "everything is difficult to be understood " because most complex texts, like literary texts, cannot be easily without loss in meaning. The other reason behind Schalkwyk's view is that "Shakespeare language is very difficult for readers " because he is SHAKESPEAER, who uses a unique set of linguistic patterns that cannot be easily depicted by many reader. Scholars, such as Schalkwyk (2006: 38), assert that there is a need to give a set of relationships between the parts of the text as Shakespeare does.

To sum up, the readers has a wide selection of scenery levels in the course of interpretation, and such selection depends on linguistic and cultural competence. This selection plays a role in the accuracy versus inaccuracy to reflect the function of the renditions taken from Shakespeare's drama.

\section{Methodology}

\section{Introduction}

The current section presents the methods and procedures adopted by the researcher to gather the research material to be analyzed. It also includes sample of the study, data collection, limitations of the study, and finally, the criteria and methodology for the classification of puns as they will appear in the analysis part.

By picking up examples from Shakespeare's plays and their renditions into their interpretation. The researcher hope to highlight problems in understanding pun. As a result, the present study is an attempt to evaluate the understanding of some Shakespeare's puns .

\section{Criteria and Method Adopted in Data Analysis}

The following is an account of the procedure of this analysis:

- Each pun is analyzed separately. The researcher presents the English text together with its interpretation.

- Selected puns examined with the attempt to make a critical analysis of them.

- The researcher sought to point out how appropriately Shakespeare's puns were rendered into their meaning by studying them from a socio-cultural point of view.

- In the process of analysis (discussion), the researcher discusses in depth with logical interpretation to get the real meaning of the pun.

\section{Data of the Study}

The researcher collected the main body of this research from Shakespeare's plays mentioned in the "Riverside Shakespeare". (The researcher will study in depth). The process of pun's translation starts with the selection of puns to be used in testing. Thirty examples of Shakespeare's puns studied. Most of the selected puns were collected from different plays of Shakespeare. These puns were mostly selected on the basis of being rich domain. These puns are good enough to be used for readers as testing and evaluating and to reflect the readers problems that Shakespeare's puns translation suffers from. The researcher predicts that puns are problematic by comparing the original meaning of the texts with their misunderstanding. For this study, the puns that have been chosen are divided into groups and analyze them in the course of discussion. Understanding puns differently by readers indicates that although some readers may be talented enough in the language and professionals, there were deviations and differences from the real meaning.

The researcher compared and contrasted the texts in terms of syntax, semantics and style. He was able to establish the extent of deviations from the original meaning ie reach the accepted interpretation. A total of thirty English Shakespearean puns were used to be analyzed.

\section{Analysis and Discussion}

\section{Introduction}

In this part, the researcher tries to analyze puns used by Shakespeare in his use of language, some stylistic features of his plays in which pun is employed, followed by a discussion of the functions of this rhetorical device in drama, in general, and in the drama of Shakespeare, in particular, are presented.

Puns in The Taming of the Shrew

To give a first and very simple example from The Taming of the Shrew, let us first shed some light on the background of

\section{Volume 4 Issue 12, December 2015}




\section{International Journal of Science and Research (IJSR) \\ ISSN (Online): 2319-7064}

Index Copernicus Value (2013): 6.14 | Impact Factor (2014): 5.611

Shakespeare's speech or, say, the context in which the pun appeared.

Katherine says to her father whom she thinks has belittled her before the men who view her as a Shrew.Katherine is far from being a static or simple character. Taken in context, her claim to inferiority can only be taken as a sign of modesty and politeness. However, her insistence to reject Petrocio, despite the attempts to dissuade her, shows that Katherine views herself as a paragon of bravery, integrity, courtesy, and virtue. Petrocio's response testifies to both his humility and ambition, and shows his modesty to be mixed with complacency and self-confidence.

By the end of the story, she changes and grows wiser as she discovers her basic weakness and acknowledges it. She discovers herself as an imperfect woman by nature.

Kath. I pray you, sir, is it your will

To make a stale of me amongst these mates?

Hortensio, upon hearing her statement replies,

Hor. Mates, maid! How mean you that? No mates for you

Unless you were of gentler, milder mold

The Taming of the Shrew (II. i)

Another example from the Taming of the Shrew is this one:

Pet.... For I am he am born to tame you, Kate,

And bring you from a wild Kate to a Kate

Conformable as other household Kates.

Here comes your father. Never make denial;

I must and will have Katherina to my wife. Note that

The Taming of the Shrew (II. i)

(1) Kate: cat (cat was pronounced as Kate in the age of Shakespeare).

(2) Kate: a delicious dainty woman.

A third pun taken from The Taming of the Shrew is found in (II, i):

Kath. Asses are made to bear; and so are you.

Pet. Women are made to bear, and so are you. The Taming of the Shrew (II. i)

(Note that Bear: carry: with following puns on "bear children" and "support a man during sexual intercourse").

(1) To carry loads.

(2) To carry their babies (to get pregnant).

In this example, the pun takes place in the last word. The word 'bear' bears two meanings in this context. But this is by no means the intended meaning. Rather, because of the 'hidden' indication of the story, the receptor is expected to consider the 'remote' meaning of the word.

\section{Puns in The Merchant of Venice}

TheMerchant of Venice is classified as both an early Shakespearean comedy (more specifically, as a "Christian comedy") and as one of the Bard's problem plays; it is a work in which good triumphs over evil, but serious themes are examined and some issues remain unresolved.

TheMerchant of Venice is a tragic comedy. It is believed to have been written between 1596 and 1598 .

In Merchant, Shakespeare wove together two ancient folk tales, one involving a vengeful, greedy creditor trying to exact a pound of flesh, the other involving a marriage suitor's choice among three chests and thereby winning his (or her) mate. Shakespeare's treatment of the first standard plot scheme centers around the villain of Merchant, the Jewish moneylender Shylock, who seeks a literal pound of flesh from his Christian opposite, the generous, faithful Antonio. Shakespeare's version of the chest-choosing device revolves around the play's Christian heroine Portia, who steers her lover Bassanio toward the correct humble casket and then successfully defends his bosom friend Antonio from Shylock's horrid legal suit.

In the modern, post-Holocaust readings of Merchant, the problem of anti-Semitism in the play has loomed large. A close reading of the text must acknowledge that Shylock is a stereotypical caricature of a cruel, money-obsessed medieval Jew, but it also suggests that Shakespeare's intentions in Merchant were not primarily anti-Semitic. Indeed, the dominant thematic complex in The Merchant of Venice is much more universal than specific religious or racial hatred; it spins around the polarity between the surface attractiveness of gold and the Christian qualities of mercy and compassion that lie beneath the flesh.

Bassanio, a Venetian nobleman with financial difficulties, wishes to compete for the hand of Portia, a wealthy heiress of Belmont, in order to restore his fortune. He asks his friend Antonio, a successful merchant of Venice, to loan him the money necessary to undertake such an attempt. Antonio agrees, but, as all of his assets are tied up at sea, he will have to use his credit in order to obtain the money for his friend. They go to Shylock, a Jewish moneylender and enemy of Antonio's. Shylock agrees to lend them 3000 ducats, but only if Antonio will sign a bond offering the usurer a pound of his flesh if the loan is not repaid in three months' time. Despite Bassanio's misgivings, Antonio assents to the arrangement.

They state that whoever seeks to marry Portia must solve the riddle of the three caskets- one gold, one silver, one lead, each with an inscription- or, failing in the attempt, agree to remain a bachelor for the rest of his days. Various suitors attempt the test and fail, until Bassanio arrives. Portia favors him and is delighted when he succeeds. His man, Gratiano, also proposes to Nerissa. She accepts.

But all is not well in Venice. Lorenzo, a friend of Bassanio and Antonio, elopes with Shylock's daughter, Jessica. This enrages Shylock, who vows to show no mercy.

Let us start off with this one from The Merchant of $\operatorname{Venice}(\mathrm{V}, \mathrm{i})$ :

Portia. Even so void is your false heart of truth.

By heaven, I will ne'er come in your bed

Untill I see the ring!

Gratiano. I'll fear no other thing,

So sore as keeping so for Nerissa's ring.

The Merchant of Venice (V.i)

\section{Volume 4 Issue 12, December 2015}




\section{International Journal of Science and Research (IJSR) \\ ISSN (Online): 2319-7064}

Index Copernicus Value (2013): 6.14 | Impact Factor (2014): 5.611

Mutran's translation of the above lines reads:

Puns in Much Ado about Nothing

Much Ado about Nothing is a comedy written by Shakespeare about two pairs of lovers, Benedick and Beatrice, and Claudio and Hero. Stories of lovers deceived into believing each other false were common currency in northern Italy in the sixteenth century. Benedick and Beatrice are engaged in a "merry war"; they both talk a mile a minute and proclaim their scorn for love, marriage, and each other. In contrast, Claudio and Hero are sweet young people who are rendered practically speechless by their love for one another. By means of "noting" (which sounds the same as "nothing," and which is gossip, rumor, and overhearing), Benedick and Beatrice are tricked into confessing their love for each other, and Claudio is tricked into rejecting Hero at the altar. However, Dogberry, a Constable who is a master of malapropisms, discovers the evil trickery of the villain, the bastard Don John. In the end, Don John is captured and everyone else joins in a dance celebrating the marriages of the two couples.

Beat the count is neither sad

Nor sick, nor merry, nor well

But civil, count, civil as an orange,

And something of that jealous complexion.

Much Ado about Nothing (II. i)

"...Civil as an orange" to describe his jealously and bitterness (Seville orange is bitter and yellowish in color).

Context: Beatrice is referring to the character Claudio.

Hint: There is a type of bitter orange that comes from Seville, Spain.

Another pun from Much Ado about Nothing is found in (III. iv):

Beat. I am out of all other tune, methinks.

Marg. Clap's into "light a' love";

That goes without a burden.

Do you sing it, and I'll dance it.

Much Ado about Nothing (III. iv)

Burden: bass under song (but with punning reference to "weight of a man on a woman.")

\section{Puns in Richard III}

Richard III is a history play by William Shakespeare, believed to have been

written in approximately 1591 . It depicts the Machiavellian rise to power and subsequent short reign of Richard III of England. The play begins with Richard describing the accession to the throne of his brother, King Edward IV of England, eldest son of the late Richard, Duke of York.

Glou. Now is the winter of our discontent

Made glorious summer by this son of York;

And all the clouds that low'r'd upon our house

In the deep bosom of the ocean buried.

Richard III (I. i)

Context: These are the opening lines of Richard III. King Richard III was the son of the Duke of York. (Son/sun) ("sun of York" is a punning reference to the badge of the "blazing sun," which Edward IV adopted, and "son of York", i.e., the son of the Duke of York.)

The speech reveals Richard's jealousy and ambition, as his brother rules the country successfully. Richard is an ugly hunchback who is "rudely stamp'd", "deformed, unfinish'd", and cannot "strut before a wanton ambling nymph."

The play is dominated by Richard the hunchback Duke of Gloucester who becomes King Richard III but only through a series of horrible acts, killing off his enemies, his kinsmen, his wife and most of his supporters before reaching the Battle of Bosworth and crying out "My kingdom for a horse." Richard is portrayed as a pure, self-professed villain of monstrous proportions. His evil drives the plot, and until his final defeat by the Duke of Richmond (who became Henry VII) in the play's last act, the good forces opposing him are weak, splintered, and easy prey for his schemes.

\section{Puns in Henry IV}

Henry IV, Part 1 is a history play by William Shakespeare, believed to have been written no later than 1597. Henry IV has two main plots that intersect in a dramatic battle at the end of the play. The first plot concerns King Henry IV, his son, Prince Harry, and their strained relationship. The second concerns a rebellion that is being plotted against King Henry by a discontented family of noblemen in the North, the Percys, who are angry because of King Henry's refusal to acknowledge his debt to them. The play's scenes alternate between these two plot strands until they come together at the play's end.

If reasons were as plentiful as blackberries,

I would give no man a reason upon compulsion, I.

Henry IV (I. iv)

(Note that: Reason was pronounced raisin in Shakespeare's days)

\section{Puns in Romeo and Juliet}

Although tragic in nature and conclusion, Romeo and Julietis filled with humor. Shakespeare has enlivened the story with delightful characters and wonderful wit in order to lighten the bitterness of the tragedy. Puns in Romeo and Juliet helped to make this tragic love story a bit lighter. No one can doubt the sheer brilliance of William Shakespeare. Here was a man that changed the entire face of the English language. Of the many plays that Shakespeare penned, one of the most famous one that has become synonymous with love stories is Romeo and Juliet. Shakespeare, even in the midst of a tragic love story, managed to keep the humor factor alive in the form of puns in Romeo and Juliet.

The opening scene of the play is filled with puns. Mercutio's speech is always full of wit and humor. His wit is the product of his intellectual sharpness; his humor is a product of his poking fun at other people's weaknesses. On Romeo's love sickness, he says:

"Alas, poor Romeo! He is already dead: stabbed with a white wench's black eye; shot through the ear with a love song." Tybalt, he calls "Prince of cats". 


\section{International Journal of Science and Research (IJSR) \\ ISSN (Online): 2319-7064}

Index Copernicus Value (2013): 6.14 | Impact Factor (2014): 5.611

Romeo, instead of being the butt of Mercutio's witty attack, proves an equal match to him. Romeo remarks that Mercutio is a gentleman that loves to hear himself talk and will speak more in a minute than he will stand to in a month. After being stabbed by Tybalt, Mercutio even speaks humorously from his deathbed, saying:

"Ask for me tomorrow and you shall find me a grave man." Shakespeare uses comic relief throughout the play to lighten the tragedy to which the play is hurtling.

Characters in Shakespeare's plays use puns to discuss love and their emotions. One of the first conversations in the play involves many crude puns spoken by the two servants, Sampson and Gregory.

In this opening speech, Sampson and Gregory use the words colliers, collar, choler, and carry coals to point out the different meaning of the same word. Therefore these two are using puns in their conversation. Carry coals means to submit insults, colliers are workers in coal, in choler means to be angry, and a collar is a hangman's noose. Also, a pun is made with maidenheads, which is used as thee heads of maidens and virginity. Naked weapon refers to an unsheathed sword and a male reproductive organ. To the wall refers to a sexual term as well its literal meaning. In this way Gregory and Sampson say the same word multiple times, but are using it in different contexts and with different meanings.

There are certain characters that can be found to be humorous in many ways. Mercutio always uses puns deliberately while Peter indulges in witty punning at all the inappropriate times. The nurse tends to bring out the humor by using puns and by repeating statements she has said before. These different characters have been added so as to lighten the atmosphere and add a touch of reality to the story. Shakespeare was a brilliant punster and used puns for many purposes in his plays. They helped to lighten a tragic scene or at times, managed to stump the audience when delivered correctly or sometimes, even camouflaged a situation or a feeling that a person is actually trying to convey. Given below are a few examples of puns in Romeo and Juliet.

In William Shakespeare's Romeo and Juliet, one of Romeo's friends Mercutio has a sense of humor, and often makes jokes. This quality remains with him up to the point when he is fatally stabbed by Juliet's cousin Tybalt, while trying to defend Romeo in Act III. Scene. i.

Romeo, at first thinking that Mercutio's wound is not serious, says "Courage, man; the hurt cannot be much."

However, some of his puns were more complicated. For example, inRomeo and Juliet when Mercutio begs Romeo to dance, Romeo refuses. Unlike Mercutio's shoes with "nimble soles," Romeo says that he has a "soul of lead." At one point, Romeo asks for a torch, saying "being heavy [sad], I will bear the light." One of the cleverest ad most morbid poems comes as a joke from a fatally-stabbed Mercutio, who steps joking to explain that:
(Note that grave means serious, but here it also alludes to his immanent death)

Mercutio (on being fatally wounded) replies:

"No, 'tis not so deep as a well, nor so wide as a church-door; but 'tis enough, 'twill serve; ask me for to-morrow, and you shall find me a grave man..."

Rom. Give me a torch; I am not for this ambling; Being but heavy, I'll bear the light.

Romeo and Juliet (I. iv)

Heavy: sad (in a bad mood), weighing much

Light: weighing little not (weighing much); brightness (a torch)

Mer. Nay, gentle Romeo, we must have you dance.

Rom. Not I. Believe me. You have dancing shoes

With nimble soles; I have a soul of lead

So stakes me to the ground I cannot move.

Romeo and Juliet (I. iv)

(Note that Romeo used the word sole to refer to the bottom of Mercutio's shoe and then uses the word to refer to his own soul)

Context: Romeo is reluctant to attend a party because he is suffering from a broken heart.

Romeo and his friends disguised in masks except for Mercutio, arrive outside Capulet's house. Romeo says he is too heavy- hearted to dance, and Mercutio tries unsuccessfully to argue him into a happier mood. Benvolio points out that they will be too late for the feast if they go on talking, and this puts an end to the discussion.

\section{Another example is also from Romeo and Juliet}

Context: Mercutio and Benvolio are talking in the street when Tybalt enters looking for Romeo, and a quarrel develops between Tybalt and Mercutio. At this moment Romeo enters and is insulted by Tybalt, but having just been secretly married to Juliet, he is unwilling to quarrel with any member of her family, and so declines to fight Tybalt. Mercutio, who is ignorant of any relationship between Romeo and Juliet, and is annoyed by what seems to him Romeo's cowardice, fights Tybalt himself. Romeo tries to separate them, and keep the peace, but Tybalt wounds Mercutio with a cowardly blow under Romeo's arm, and runs away. Benvolio helps Mercutio to a neighboring house, but soon return to report that Mercutio is dead. Romeo is so angered by this slaying of the friend who had fought on his behalf, that when Tybalt appears, he fights and kills him. He escapes just before the Prince and the city authorities arrive on the scene. Benvolio tells them all that has happened. The Prince banishes Romeo from the city and declares that he will be put to death if he returns. He also imposes a heavy fine upon the two families whose enmity has been the cause of the bloodshed.

Mer. No, 'tis not so deep as a well, nor so wide as a church-door, but 'tis enough, 'twill serve. Ask for me to-morrow, and you shall find me a grave man.

Romeo and Juliet (III.i)

Hint: Grave=serious, dead, sad.

"tomorrow....you shall find me a grave man."

\section{Volume 4 Issue 12, December 2015}




\section{International Journal of Science and Research (IJSR) \\ ISSN (Online): 2319-7064}

Index Copernicus Value (2013): 6.14 | Impact Factor (2014): 5.611

Context: Paris comes to visit Juliet's tomb. His Page, Hiding in the churchyard whistles to warn him of the approach of Romeo and Balthasar, and he too, hides. Romeo gives Balthasar a letter to deliver to his father, and tells him to go right away from the vault, but Balthasar suspects Romeo's intentions and hides in the churchyard and to see what happens. As Romeo breaks open the gate of the vault, Paris comes forward and tries to arrest him, ignoring Romeo's appeals that he should go away. They fight and Paris is killed, and at his request, Romeo lays him besides Juliet's tomb. Romeo kisses Juliet for the last time, drinks the poison, and dies, just before Friar Lawrence reaches the vault. He enters just as Juliet wakes and discovers the bodies of Romeo and Paris. They hear the voices of the Watch, who have been summoned from the city by the Page, but Juliet refuses to leave, and Friar Lawrence hurries away alone. Juliet kisses Romeo, hoping that the poison on his lips will kill her, but as the voices come near she stabs herself with Romeo's dagger, and dies beside him. The watch arrive, search the churchyard, and arrest the Friar and Balthasar. The Prince enters the vault, closely followed by the Capulets and Muntagues. Friar Lawrence tells the story of the lovers, and the truth of his account is proved by Romeo's letter. The Prince traces the source of source of these tragic events to the hatred between the two families, and at last the Montagues and Capulets are reconciled, and determine to build golden statues to the memory of Romeo and Juliet.

Pag. We see the ground whereon these woes do lie,

But the true ground of all these piteous woes,

We cannot without circumstance descry.

Romeo and Juliet (V. iii)

Ground: earth, reason

The puns are frequently lewd in nature and, more often than not, tend to have sexual innuendos. However, we must understand that this play is written keeping in mind the Victorian era. The audience at that time immensely enjoyed such puns. After all, imagine a setting where doubleentendres and puns in Romeo and Juliet are being said out loud in a play with a rapt audience trying to grapple with what is being said against what is being implied. Truly, this is where the beauty of English lies!

Later, in Scene III, Juliet says to her mother "What is your will?" At first it seems like Juliet just wants to know what her mother wants, but it is actually a joke by Shakespeare. It compares her mother to Juliet's will, because Juliet will die later in the play. The "will" here is a pun, referring to Juliet's last will and testament after she dies. Another example is:

Context: It is later that same Monday morning. Benvolio tells Mercutio that Tybalt has sent a letter demanding a fight with Romeo. Mercutioo is making fun of Tybalt's affected manners when Romeo enters, and Mercutio tries to make him forget his love affair by engaging him in a battle of wits. The Nurse, sent as arranged, by Juliet, comes looking for Romeo and Mercutio and Benvolio leave. Romeo instructs the Nurse to get Juliet to come that afternoon to Friar Lawrence's cell, as if it to confession, but really in order to be married. He arranges to send the Nurse a rope ladder, to be let down that night from Juliet's window, so that he can enter unseen by the Capulet.
Rom. What hast thou found?

Mer. No hare, sir, unless a hare, sir, in a Lenten pie,

That is something stale and hoar ere it be spent.

[He walks by them and sings.]

An old hare hoar,

And an old hare hoar, is very good meat in Lent;

Romeo and Juliet (II,iv)

Hoar: mouldy (with pun on whore)

\section{Puns in A Midsummer Night's Dream}

In A Midsummer Night's Dream, we find a variation on Shakespeare's usual puns. In a complex variant on the pun, he has characters confuse words with other words that sound (more or less) the same but have very different meanings. (Such verbal confusions are now called "malapropisms"). Bottom is particularly inclined to this kind of speech. When he says, for example,

But I will aggravate my voice so that I will roar you as gently as any sucking dove, he seems to be confusing aggravate with moderate or mitigate (soften, tone down). (In a different kind of confusion, his reference to the "sucking dove" mixes up the sucking [i.e., unweaned] lamb and the sitting [i.e., hatching] dove.) When he says

\section{There we may rehearse most obscenely and courageously,}

$\mathrm{He}$ is confusing "obscenely" with some other word (probably seemly) and confusing courageously either with a word that sounds a bit like it (perhaps, correctly) or perhaps with the word bravely, which had the meaning both of "courageously" and of "splendidly, in a fine fashion".

Shakespeare's wordplay in A Midsummer Night's Dream is particularly interesting in the way it varies his usual use of puns and figurative language. Helena says:

Hele. ...For'er Demetrius look'd on Hermia's eyne

He hail'd down oaths that he was only mine;

And when this, hail some heat from Hermia felt,

So he dissolv'd, and show'rs of oaths did melt.

A Midsummer Night's Dream (I, i)

The first use of the word hail means "to shower down, to pour," but, since it sounds exactly like the verb hale, it also carries the sense of "pull down," as if the oaths were being tugged down from the sky. The second use of the word hail, in the following line, is as a noun, and Demetrius's oaths are given the characteristics of hail: they feel heat, dissolve, and melt. This shift from hail/hale as a verb to hail as a noun is an interestingly complex pun.

\section{Conclusion Recommendations Suggestions for Further Studies}

Here, the researcher addresses the conclusions of this study at two levels. The first level presents conclusions concerning the specific sample chosen for the analysis. Being classified according to their functions in Shakespeare's drama, there might be special ways of handling them. Consequently, different conclusions might be arrived at. This level is followed by another focusing on general conclusions based on the study as a whole.

After analyzing and discussing the selected renditions, the researcher has also come up with the following conclusions:

\section{Volume 4 Issue 12, December 2015}




\section{International Journal of Science and Research (IJSR) \\ ISSN (Online): 2319-7064}

Index Copernicus Value (2013): 6.14 | Impact Factor (2014): 5.611

- Setting should be given priority in understanding pun expressions.

- Context plays a very important role in understanding pun expressions appropriately and correctly.

- Deleting the pun expression results in a considerable loss at the informative and expressive levels.

- Reducing pun into another figure of speech leads to loss at the aesthetical level.

- Having a good knowledge of Shakespeare language is the only solution for a good understanding of his puns.

- Without good knowledge of Shakespeare pun will be misleading.

- Deep thinking is important for understanding Shakespeare language.

- The ultimate goal deep thinking is to achieve harmony between words and to avoid distortion of the information of hidden meanings of puns.

- Having insufficient knowledge of Shakespeare language causes misunderstanding of the essence of the pun.

Based on the above investigation and discussion conducted in this study, the researcher recommends that further researches must be conducted on the understanding of pun to find out to which extent, the reader can reach the optimal meaning for a pun. Further studies on understanding of Shakespeare's plays dealing with other figures of speech are also recommended. Still, for any reader to succeed in his understanding of any dramatic work, it is also recommended that $\mathrm{s} / \mathrm{he}$ has a sense of admiration and appreciation of drama and its aesthetic value. Instead, enjoying the task and feeling the ability to be creative helps the reader to arrive at good results.

Based on the findings of this study, and in order for a translator to gain more success and effectiveness in the understanding of a certain work of drama, s/he should read deeply and intensively anything available on the life of the playwright before embarking on the understanding the message of the writer's style. The writer's beliefs; dreams; likes and dislikes; issues of interest; and what s/he aims at conveying through her/his works. Some details that seem to be of insignificance at the beginning might turn out to play the greatest role in, first, monitoring the work, and then managing to understand it.

As we have seen earlier, understanding pun is a thorny area and it is not easy to deal with. Hence, the following are recommended:

Further studies in understanding punsshould be conducted in order to highlight the cultural obstacles the reader may face in dealing with Shakespeare's puns and suggest suitable strategies to overcome such obstacles.

It is also recommended that further studies should be carried out in the field of style assessment from a cultural perspective as culture is a very important element in understanding, and because such studies enhance the situation of understanding Shakespeare's puns writing.
In order to understand drama communicatively, the reader must be familiar with the play's style, rhetoric, substance and the intended meaning

Readers are advised to read the Shakespeare's pun analytically and appreciatively to assimilate its content and its style, especially with reference to their cultures and ideologies.

Readers should stress on the need for a sense of creativity particularly when attempt to understand a literary masterpiece.

Although the nature of pun is problematic area of understanding. It is still a figure of speech, which plays a very important role that should never be underestimated.

Lastly, more research that deals with understanding other Shakespeare's puns and other figures of speech are needed.

\section{References}

[1] Brown, G. \& Yule, G. (1983). Discourse Analysis. Cambridge, New York. Cambridge University Press.

[2] Culler, J. (1988). On Puns: The Foundation of Letters.Oxford \& New York: Basil Blackwell.

[3] Empson, W. (1966). Seven Types of Ambiguity.New York: New Directions Publishing Corporation.

[4] Hornby, A.S. (1974). Oxford Advanced Learner's Dictionary of Current English. London: Oxford University Press.

[5] Leech, G. N. (1969). A linguistic guide to English poetry. New York: Longman.

[6] Lyons, J. (1965). Linguistic semantics: An introduction. New York: Cambridge University Press.

[7] Mahood, M.M. (1968). Shakespeare's Wordplay. New York Press

[8] Merriam-Webster's Collegiate dictionary ( $9^{\text {th }}$ ed.). (1991). Springfield. MA: Merriam-Webster

[9] Mueck, D. C. (1970). Irony and ironic.London: Methuen.

[10] Palmer, F. R. (1981). Semantics. (2 $2^{\text {nd }}$ Ed.). Cambridge: Cambridge University Press.

[11] Shunnaq, A. (1992). Monitoring and Managing in the Language of Broadcasting and Newspapers. Irbid: Dar Al-Amal.

[12] Su, S. P. (1994). Lexical ambiguity in poetry.London: Longman.

[13] Thornborrow, J. \&Wareing, S. (1998). Pattern in Language: An introduction to language and literary style. London: Routledge.

[14] Wiggin, E. (2001). Puns and other wordplay. Retrieved July $20, \quad 2011, \quad$ from http://www.bbc.co.uk/dna/h2g2.

[15] Wikipedia, the free encyclopedia. (n.d.). pun. Retrieved in June 16, 2010 from http: //en.wikipedia.org/wiki/pun.

[16] Yule, G. (1996). The study of language. (2 $2^{\text {nd }}$ Ed.). Cambridge: Cambridge University Press. 